\title{
A REGRA DE OURO DAS FINANÇAS PÚBLICAS E A ADI N. 5.683/RJ: A CONSTITUIÇÃO FEDERAL PERMITE FINANCIAR DESPESAS CORRENTES COM OPERAÇÕES DE CRÉDITO?
}

\section{Giovanna Montellato Storace Rota}

Mestra em Direito Econômico, Financeiro e Tributário e Graduada em Direito pela Faculdade de Direito da Universidade de São Paulo. Advogada.

\section{SUMÁRIO}

Considerações iniciais - 1 . A regra de ouro das finanças públicas 2. O processo da medida cautelar na ADI n. 5.683/RJ - 3. A decisão monocrática em sede de medida cautelar na ADI n. 5.683/RJ - Considerações finais - Referências. 


\section{CONSIDERAÇÕES INICIAIS}

Esse artigo tem por objetivo analisar a decisão monocrática proferida em 29 de agosto de 2017 pelo Ministro do Supremo Tribunal Federal Luís Roberto Barroso em sede de medida cautelar na Ação Direta de Inconstitucionalidade (ADI) n. 5.683/RJ, confrontando-a com a compreensão que se tem da chamada "regra de ouro das finanças públicas".

A ADI n. 5.683/RJ foi ajuizada em 29 de março de 2017 pelos partidos políticos Rede Sustentabilidade (Rede) e Partido Socialismo e Liberdade (PSOL), questionando a constitucionalidade material da Lei n. 7.529/2017 do Estado do Rio de Janeiro, em face dos artigos 37 e 167, incisos III e X, da Constituição Federal, com pedido de medida cautelar para suspender a eficácia do inteiro teor da lei impugnada até o julgamento final da ação.

A petição inicial também alega a inconstitucionalidade formal da lei impugnada, em face de diversos dispositivos da Constituição Federal relativos ao processo legislativo, o que não integrará o objeto de análise desse artigo. Da mesma forma, não serão analisadas questões processuais, como o pedido da Assembleia Legislativa do Estado do Rio de Janeiro para que a ADI fosse redistribuída por prevenção em razão da Ação Cível Originária n. 2.981/RJ. ${ }^{1}$

A Lei n. 7.529/2017 do Estado de Rio de Janeiro autoriza o seu Poder Executivo a alienar a totalidade das ações representativas do capital social da Companhia Estadual de Águas e Esgotos - CEDAE $\left(\operatorname{artigo~} 1^{\circ}\right.$ ), sociedade de economia mista estadual que realiza a captação, tratamento, adução e distribuição das redes de água e a coleta, transporte, tratamento e destino final dos esgotos em municípios conveniados. ${ }^{2}$

Ainda, a Lei autoriza que, enquanto essa alienação não for efetivada, o Poder Executivo contrate operação de crédito de até 3,5 bilhões de reais junto a instituições financeiras nacionais ou internacionais, organismos multilaterais e bilaterais de crédito, agências de fomento ou agência multilateral de garantia de financia-

1 A Ação Cível Originária n. 2.981/RJ tem por objeto o Termo de Compromisso para Recuperação Fiscal do Estado do Rio de Janeiro, firmado entre o Estado do Rio de Janeiro e a União Federal. A distribuição por dependência da ADI n. 5.683/RJ foi alegada tendo em vista que a Lei Estadual n. 7.529/2017 teria previsões necessárias ao cumprimento do acordo. Entretanto, em sua decisão monocrática, o Ministro Luís Roberto Barroso rejeitou a preliminar de redistribuição da ADI por prevenção.

2 Companhia Estadual de Águas e Esgotos - CEDAE. Apresentação. Disponível em <http:// www.cedae.com.br/apresentacao >. Acesso em: 16 jul. 2018. 
mentos (artigo $2^{\circ}$ ) e ofereça as ações da CEDAE como garantia à instituição credora ou como contragarantia à União Federal (artigo $2^{\circ}$, parágrafo $1^{\circ}$ ).

A Lei ainda prevê, em seu artigo $2^{\circ}$, parágrafo $2^{\circ}$, que “os recursos resultantes da operação de crédito prevista no caput deverão ser prioritariamente utilizados no pagamento da folha dos servidores ativos, inativos e pensionistas" e que os recursos obtidos com a alienação das ações representativas do capital social da CEDAE serão obrigatoriamente utilizados na quitação da operação de crédito autorizada e o saldo será destinado ao abatimento de outras dívidas (artigo $5^{\circ}$, caput e parágrafo único).

Em suma, o objetivo dessa Lei é permitir a alienação das ações de sociedade de economia mista para o pagamento de despesas com pessoal, por intermédio da contratação de operação de crédito.

Segundo as informações prestadas em 24 de abril de 2017 pelo Governador do Estado do Rio de Janeiro no curso da ADI, a Lei Estadual n. 7.529/2017 foi editada com o objetivo de cumprir o Termo de Compromisso firmado entre o Estado do Rio de Janeiro e a União Federal, a fim de promover o reequilíbrio financeiro-fiscal desse Estado-membro, vez que, dentre as medidas previstas no acordo, estaria a alienação das ações da CEDAE.

Nesse sentido, reproduz-se a Cláusula Quarta, item vii, do Termo de Compromisso:

O Estado do Rio de Janeiro se compromete a: (...)

vii) de modo irretratável e irrevogável, promover a alienação da integralidade das ações da Companhia Estadual de Águas e Esgotos (CEDAE) detidas pelo ERJ, sendo que os recursos obtidos com a alienação deverão ser utilizados integralmente na amortização de dívidas, tendo em vista a seguinte ordem: dívidas novas, dívidas refinanciadas com bancos federais garantidas pela União e dívidas com a União, observado o disposto no art. 44 da Lei Complementar n. ${ }^{\circ} 101$, de $2000^{3}$.

Assim, a edição dessa lei e os questionamentos acerca da sua constitucionalidade se inserem no contexto da crise financeira do Estado do Rio de Janeiro.

Do ponto de vista jurídico, essa crise financeira foi marcada pelo Decreto n. 45.692, de 17 de junho de 2016, que estabeleceu estado de calamidade pública na administração financeira do Estado do Rio de Janeiro, apontando como causas

3 BRASIL. Termo de Compromisso que entre si celebram o Estado do Rio de Janeiro e a União. Disponível em <http://tesouro.fazenda.gov.br/documents/10180/0/Termo+de+compromisso+ RJ/81f7368e-43d6-4c90-ba45-e189db359f2a>. Acesso em: 16 jul. 2018. 
para a situação a queda na arrecadação tributária, notadamente a título de ICMS (Imposto sobre circulação de mercadorias e serviços) - reflexo da crise econômica nacional - e a redução dos valores recebidos pelo Estado a título de royalties de petróleo.

Contudo, outros motivos são considerados relevantes para a formação do cenário, como a alargada concessão de benefícios fiscais pelo Estado, a má gestão das finanças públicas estaduais e o excesso de gastos públicos, em especial despesas com pessoal e previdência de servidores estaduais. ${ }^{4}$

Segundo Pedro Jucá Maciel,

[o] Rio de Janeiro quebrou por excesso de gastos obrigatórios, aumento de gastos com pessoal acima do permitido pela Lei de Responsabilidade Fiscal, e não por endividamento. $\mathrm{O}$ governo fluminense também contou com receitas temporárias, como os royalties do petróleo, para expandir gastos permanentes, inchando a máquina 5 .

Nesse contexto, a Lei de Diretrizes Orçamentárias do Estado do Rio de Janeiro para o exercício financeiro de 2018 foi aprovada com uma previsão de déficit de mais de 20,3 bilhões de reais. ${ }^{6}$ Já na Lei Orçamentária Anual para o exercício financeiro de 2018, a previsão de déficit foi reduzida para cerca de 10 bilhões de reais, por conta da interrupção no pagamento de dívidas em face da União Federal, em razão do Regime de Recuperação Fiscal, o que gerou uma diminuição nas despesas previstas no orçamento estadual. ${ }^{7}$

4 PUFF, Jefferson. 4 motivos que levaram o Rio a decretar estado de calamidade pública. BBC Brasil, Rio de Janeiro, 18 jun. 2016. Disponível em <https://www.bbc.com/portuguese/brasil-36566996>. Acesso em: 16 jul. 2018 e CARTA CAPITAL. Entenda a crise e as razões da revolta de servidores no Rio de Janeiro. Carta Capital, 21 nov. 2016, Política. Disponível em $<$ https://www.cartacapital.com.br/politica/entenda-a-crise-e-a-revolta-dos-servidores-no-rio-de-janeiro>. Acesso em: 16 jul. 2018.

5 Cf. PUFF, Jefferson. Op. cit.

6 ESTADO DO RIO DE JANEIRO. Anexo de Metas Fiscais da Lei de Diretrizes Orçamentárias 2018, p. 112. Disponível em <http://www.fazenda.rj.gov.br/sefaz/content/conn/UCMServer/ path/Contribution\%20Folders/site_fazenda/Subportais/PortalPlanejamentoOrcamento/2_ ppa_ldo_loa/ldo/ldo2018.pdf?lve>. Acesso em: 16 jul. 2018.

7 ESTADO DO RIO DE JANEIRO. Lei Orçamentária Anual 2018, p. 43. Disponível em <http:// www.fazenda.rj.gov.br/sefaz/content/conn/UCMServer/uuid/dDocName\%3aWCC207416>. Acesso em: 16 jul. 2018; e BARREIRA, Gabriel. Rj espera déficit de R\$ 10 bi em 2018, metade do previsto antes do Regime de Recuperação Fiscal, G1, Rio de Janeiro, 03 out. 2017. Disponível em <https://g1.globo.com/rio-de-janeiro/noticia/rj-espera-deficit-de-r-10-bi-em-2018-metade-do-previsto-antes-do-regime-de-recuperacao-fiscal.ghtml>. Acesso em: 16 jul. 2018. 
Ainda assim, nota-se que quase $53 \%$ das despesas do Estado do Rio de Janeiro autorizadas para o exercício financeiro de 2018 são relativas a despesas e encargos com pessoal (salários, aposentadorias e pensões), chegando em 38,6 bilhões de reais, perante um total de despesas (correntes e de capital) de 73,1 bilhões de reais.

A preponderância das despesas com pessoal no orçamento do Estado do Rio de Janeiro ajuda a explicar tanto a crise financeira do Estado quanto a própria escolha da Lei Estadual n. 7.529/2017 em destinar prioritariamente os recursos da operação de crédito que autoriza para o pagamento da folha dos servidores ativos, inativos e pensionistas, o que gera discussões perante a regra de ouro das finanças públicas, conforme será visto a seguir.

\section{A REGRA DE OURO DAS FINANÇAS PÚBLICAS}

A alegação de inconstitucionalidade material da Lei n. 7.529/2017 do Estado de Rio de Janeiro na ADI n. 5.683/RJ se dá em face dos artigos 37 e 167, incisos III e X, da Constituição Federal.

$\mathrm{O}$ artigo 167, inciso III, da Constituição Federal estampa a chamada "regra de ouro das finanças públicas":

Art. 167. São vedados: (...) III - a realização de operações de créditos que excedam o montante das despesas de capital, ressalvadas as autorizadas mediante créditos suplementares ou especiais com finalidade precisa, aprovados pelo Poder Legislativo por maioria absoluta.

O objetivo da regra de ouro é limitar o endividamento público. Segundo Manoel Pires,

[o] princípio econômico que justifica essa regra é que o investimento, ao aumentar o estoque de capital público, beneficia várias gerações e não apenas a geração presente sobre a qual recai o ônus de financiar aquele investimento realizado. Dessa forma, é desejável que os custos do financiamento desse investimento sejam absorvidos pelas várias gerações beneficiadas e não somente pela geração presente ${ }^{8}$.

A contrario sensu, despesas que não constituam uma forma de investimento, como as despesas correntes, não devem criar ônus para as gerações futuras, não devendo ser custeadas por meio de operações de crédito.

8 PIRES, Manoel. Para entender a regra de ouro das finanças públicas. In: Blog do Instituto Brasileiro de Economia da Fundação Getúlio Vargas, 01 nov. 2017. Disponível em <https://blogdoibre.fgv.br/posts/para-entender-regra-de-ouro-das-financas-publicas>. Acesso em: 16 jul. 2018. 
De forma mais elaborada,

[d]o ponto de vista patrimonial, a regra de ouro visa à manutenção do capital líquido do ente público, ou seja, da diferença entre seus ativos (bens e direitos) e passivos (obrigações). Evita-se, desse modo, a descapitalização do ente, o que diminuiria sua capacidade de atuação futura. Desse modo, tal regra está a serviço do princípio da continuidade da prestação de utilidades públicas pelo Estado?.

Embora a literalidade do artigo 167, inciso III, da Constituição Federal apenas vede que o valor das operações de crédito exceda o montante das despesas de capital, a leitura usual que se faz desse dispositivo é a de que ele

impede o governo de promover as operações de crédito com a finalidade de custear despesas correntes (...). Por esse preceito constitucional, as operações de crédito só podem ser realizadas para custear as despesas de capital, mais precisamente as de investimento ${ }^{10}$.

No mesmo sentido, Sérgio Assoni Filho, Ana Carla Bliacheriene e César de Andrade afirmam que "[p]ela regra de ouro, é proibido o financiamento de despesas correntes, ou seja, para custeio da máquina pública, por meio de operações de crédito" ou seja, "[a] 'regra de ouro' impede que a dívida ultrapasse o montante das despesas de capital, proibindo, por conseguinte, que se financiem as despesas correntes". ${ }^{11}$

Essas afirmações decorrem da própria classificação legal das despesas públicas que engloba as definições de despesas de capital e despesas correntes.

São diversas as classificações das despesas orçamentárias e cada uma possui uma finalidade específica. Os conceitos de despesa corrente e despesa de capital se encontram na classificação por categorias econômicas, que tem por função dar indícios sobre os efeitos do gasto público sobre a economia, em es-

9 CARVAlHO JÚNIOR, Antonio Carlos Costa d'Ávila et al. Regra de Ouro na Constituição e na LRF: considerações históricas e doutrinárias - Estudo Técnico Conjunto n. 2/2017. Brasília: Consultoria de Orçamentos e Fiscalização Financeira da Câmara dos Deputados e Consultoria de Orçamentos, Fiscalização e Controle do Senado Federal, dez. 2017, p. 3.

${ }^{10}$ HARADA, Kiyoshi. Entendendo a regra de ouro das finanças públicas, 22 jan. 2018. Disponível em <http://www.haradaadvogados.com.br/2710-2/>. Acesso em: 16 jul. 2018.

11 ASSONI FILHO, Sérgio; BLIACHERIENE, Ana Carla; e ANDRADE, César Augusto Seijas de. Capítulo 4 - Dívida Pública. In: OLIVEIRA, Regis Fernandes de et. al. (coord.) Lições de Direito Financeiro. São Paulo: Editora Revista dos Tribunais, 2016, p. 105. 
pecial sua contribuição pelas alterações na renda nacional e seu caráter inflacionário ou deflacionário. ${ }^{12}$

A classificação por categorias econômicas é adotada pelo artigo 12, da Lei n. 4.320/1964 (Lei dos Orçamentos Públicos), segundo o qual as despesas correntes compreendem i) as despesas de custeio e ii) as transferências correntes e as despesas de capital compreendem i) os investimentos, ii) as inversões financeiras e iii) as transferências de capital. Ainda, como explicita o artigo 13 da mesma lei, as despesas com pessoal classificam-se como despesas de custeio e as despesas com inativos e pensionistas classificam-se como transferências correntes, todas, portanto, despesas correntes. ${ }^{13}$

Assim, observa-se que, nessa classificação, existem apenas duas categorias (apesar de múltiplas subcategorias): as despesas correntes e as despesas de capital. É em razão disso que, na previsão trazida pela regra de ouro, de que são vedadas operações de crédito além do montante previsto para as despesas de capital, se compreende, como consequência lógica, que há vedação à realização de operações de crédito para financiar despesas correntes.

Como se pode notar, a regra de ouro está intrinsecamente ligada ao equilíbrio das finanças públicas, concretizando-o em duas frentes: o equilíbrio intergeracional das finanças públicas e o equilíbrio orçamentário.

Em relação ao equilíbrio intergeracional das finanças públicas, observa-se que

a responsabilidade na gestão fiscal (...) não é um valor em si mesma e não visa a paralisar a atuação do Estado, e sim apresentar limites ao endivida-

12 GIACOMONI, James. Orçamento Público. 17ª ed. rev. e atual. São Paulo: Atlas, 2017, p. 109.

${ }^{13}$ Regis Fernandes de Oliveira esmiúça essa classificação: “as primeiras [despesas correntes] são as de custeio (pessoal civil, militar, material de consumo, serviços de terceiros e encargos diversos) e de transferências correntes (subvenções sociais, econômicas, inativos, pensionistas, salário-família e abono familiar, juros de dívida pública, contribuições de previdência social e diversas). As de capital comportam os investimentos (obras, serviços em regime de programação especial, equipamentos e instalações, material permanente, participação em constituição ou aumento de capital de empresas ou entidades industriais ou agrícolas), as inversões financeiras (aquisição de imóveis, participação em aumento ou constituição de capital de empresas ou entidades comerciais ou financeiras, aquisição de títulos representativos de capital de empresas em funcionamento, constituição de fundos rotativos, concessão de empréstimos e diversos) e as transferências de capital (amortização da dívida pública, auxílios para obras públicas, auxílios para equipamentos e instalações, auxílios para inversões financeiras e outras contribuições)" (OLIVEIRA, Regis Fernandes de. Curso de Direito Financeiro, $3^{a}$ ed. rev. e atual. São Paulo: Editora Revista dos Tribunais, 2010, pp. 277-278). 
mento do estado quando a dívida presente não represente vantagens às gerações futuras, que responderão por seu pagamento ${ }^{14}$.

Nesse ponto, a regra de ouro deve ser conjugada a outros dispositivos normativos que visam à responsabilidade fiscal e à limitação do endividamento no longo prazo para cumprir com seus objetivos.

Já do ponto de vista do equilíbrio orçamentário, considerado princípio orçamentário por parte da doutrina, a regra de ouro tem a função de limitar as despesas públicas a cada exercício financeiro.

Segundo José Augusto de Carvalho, “o princípio do equilíbrio orçamentário propugna que o total das despesas para um determinado período financeiro não seja superior ao montante das receitas previstas para esse mesmo período"15.

Assim, a regra de ouro se torna, em certa medida, uma especialização do princípio do equilíbrio orçamentário, vez que propõe que recursos advindos de operações de crédito, que se constituem receitas de capital, ${ }^{16}$ sejam destinados a despesas de capital, mantendo uma correlação de espécie e de valor entre as receitas e as respectivas categorias econômicas de despesas.

Cesar Seijas de Andrade lembra que a Constituição Federal de 1988 não impõe o equilíbrio orçamentário de forma expressa ${ }^{17}$, mas que ele "pode ser depreendido a partir de regras constitucionais que limitam o endividamento e determinam a transparência orçamentária e o controle de gastos”, citando, entre elas, a regra de ouro do artigo 167 , inciso III. ${ }^{18}$

14 ASSONI FILHO, Sérgio; BLIACHERIENE, Ana Carla; e ANDRADE, César Augusto Seijas de. Capitulo 4 - Dívida Pública..., p. 105.

15 CARVALHO, José Augusto Moreira de. O orçamento a partir de seus princípios. In: CONTI, José Mauricio; SCAFF, Fernando Facury (coord.). Orçamentos Públicos e Direito Financeiro. São Paulo: Revista dos Tribunais, 2011, p. 104.

${ }^{16}$ Lei de Responsabilidade Fiscal. "Art. 11. A receita classificar-se-á nas seguintes categorias econômicas: Receitas Correntes e Receitas de Capital. (...)

$\mathbb{S} 2^{\circ}$ São Receitas de Capital as provenientes da realização de recursos financeiros oriundos de constituição de dívidas; da conversão, em espécie, de bens e direitos; os recursos recebidos de outras pessoas de direito público ou privado, destinados a atender despesas classificáveis em Despesas de Capital e, ainda, o superávit do Orçamento Corrente".

17 O equilíbrio orçamentário já foi previsão constitucional expressa na Constituição de 1967: “Art. 66: O montante da despesa autorizada em cada exercício financeiro não poderá ser superior ao total das receitas estimadas para o mesmo período".

18 ANDRADE, Cesar Augusto Seijas de. Orçamento deficitário. In: CONTI, José Mauricio; SCAFF, Fernando Facury (coord.). Orçamentos Públicos e Direito Financeiro. São Paulo: Revista dos Tribunais, 2011, pp. 1161-1162. 
Deve-se considerar, contudo, que o equilíbrio orçamentário, embora consignado por diversos dispositivos normativos, também admite ponderações.

Além disso, alguns economistas e juristas defendem ou aceitam o endividamento público ou a apresentação de orçamentos não equilibrados em conjunturas econômicas específicas, aplicando-se a técnica do orçamento cíclico, que seria superavitário ou deficitário a depender da necessidade para compensar as variações cíclicas da economia. ${ }^{19}{ }^{20}$

Apesar dessa consideração, “atualmente, a tendência é a busca do equilíbrio orçamentário, ou seja, a equiparação entre receitas e despesas, com a finalidade de atingir a estabilidade econômica e evitar o endividamento do Estado" 21.

Após essas breves colocações sobre a regra de ouro, passa-se ao exame do processamento e julgamento, pelo Supremo Tribunal Federal, da medida cautelar na ADI n. 5.683/RJ.

\section{O PROCESSO DA MEDIDA CAUTELAR NA ADI N. 5.683/RJ}

A petição inicial da ADI n. 5.683/RJ desenvolve diversos argumentos pela inconstitucionalidade da Lei n. 7.529/2017 do Estado do Rio de Janeiro. Em relação à inconstitucionalidade material, o principal ponto levantado é que a própria finalidade da operação de crédito autorizada pela Lei é vedada pelo artigo 167, incisos III e X, da Constituição Federal, vez que os recursos obtidos seriam destinados ao pagamento de despesas correntes. A alienação das ações da CEDAE também feriria o princípio da eficiência estampado no artigo 37, da Constituição Federal. ${ }^{22}$

Ainda segundo os autores da ADI, haveria violação ao princípio da razoabilidade - ou princípio da proporcionalidade - considerando-se que a medida não atingiria o seu fim de promover o equilíbrio das contas públicas, vez que a CEDAE é empresa superavitária, que distribui dividendos ao Estado do Rio de Janeiro, e, portanto, a alienação das suas ações representaria perda de receitas públicas, agravando, no longo prazo, a crise financeira estadual. ${ }^{23}$

19 SILVA. José Afonso da. Orçamento-programa no Brasil. São Paulo: Editora Revista dos Tribunais, 1973, pp. 7-8.

20 Cf. ANDRADE, Cesar Augusto Seijas de. Orçamento deficitário..., pp. 1162-1165.

${ }^{21}$ CARVALHO, José Augusto Moreira de. O orçamento a partir de seus princípios..., p. 105.

22 BRASIL, Supremo Tribunal Federal. MC - ADI n. 5.683/RJ, Petição Inicial, j. 29.08.2017, p. 44.

${ }^{23}$ Idem, pp. 50-51. 
Por fim, requerem a declaração de inconstitucionalidade da Lei Estadual n. 7.529/2017 e a concessão de medida cautelar para suspender a sua eficácia até o julgamento definitivo da ADI.

Em seguida, foram prestadas informações pelo Governador e pela Assembleia Legislativa do Estado do Rio de Janeiro em relação ao pedido de medida cautelar. As informações prestadas pela Assembleia Legislativa focam, em especial, nas alegações de inconstitucionalidade formal relativas ao processo legislativo da Lei Estadual n. 7.529/2017 e afirmam que a alienação das ações da CEDAE é obrigação assumida pelo Estado perante a União Federal no Termo de Compromisso para adesão ao Plano de Recuperação Fiscal, argumentando a ausência dos requisitos do fumus boni iuris e do periculum in mora para a concessão da medida cautelar.

As informações prestadas pelo Governador do Estado do Rio de Janeiro seguem a mesma linha, discorrendo sobre a crise financeira estadual e lembrando outros valores constitucionais - cidadania, dignidade individual, valor social do trabalho, assistência social, saúde e educação - que, nesse momento, devem prevalecer sobre a responsabilidade fiscal. No mesmo sentido é a manifestação da Advocacia-Geral da União.

De todas as peças processuais disponíveis até o momento, a manifestação da Procuradoria-Geral da República é aquela que mais se detém na análise da alegação de inconstitucionalidade material, lembrando que o artigo 167, incisos III e X, da Constituição Federal são normas relacionadas ao equilíbrio orçamentário, demonstrando a preocupação constitucional com o endividamento público e consequente comprometimento das gerações futuras com despesas correntes.

Em razão disso, argumenta que o artigo $2^{\circ}$, parágrafo $2^{\circ}$, da Lei Estadual $n$. 7.529/2017, ao destinar os recursos que serão obtidos com a alienação da CEDAE prioritariamente ao pagamento de pessoal ativo e inativo e pensionistas, contraria as normas constitucionais.

Com relação aos argumentos levantados pelo Governador do Estado do Rio de Janeiro, no sentido da necessidade de se ponderar a responsabilidade fiscal com os demais valores constitucionais, o Procurador-Geral da República defende que as soluções para a crise financeira do Estado do Rio de Janeiro devem ser elaboradas "de acordo com as normas constitucionais, principalmente as normas de natureza orçamentária" 24 .

Lembra, ainda, que a não observância dessas normas é uma das causas da própria crise financeira do Estado e que o "respeito à ordem constitucional deve

${ }^{24}$ BRASIL, Supremo Tribunal Federal. MC - ADI n. 5.683/RJ, Manifestação do Procurador-Geral da República, j. 29.08.2017, p. 14. 
ser assegurado pelo Supremo Tribunal Federal, de forma a privilegiar a força normativa da Constituição diante da instabilidade política e econômica" ${ }^{25}$.

O Procurador-Geral da República prossegue asseverando que "privatizar empresa pública não é, por si, ato vedado pelo texto constitucional. Utilizar a medida como instrumento para obter crédito necessário ao pagamento de despesas correntes, todavia, afronta as normas constitucionais orçamentárias" e que nem a situação fática do Estado do Rio de Janeiro nem o compromisso celebrado entre o Estado e a União Federal permitem a mitigação de normas constitucionais, para concluir a manifestação pelo deferimento da medida cautelar. ${ }^{26}$

\section{A DECISÃO MONOCRÁTICA EM SEDE DE MEDIDA CAUTELAR NA ADI N. 5.683/RJ}

Apreciadas as principais peças processuais no julgamento da medida cautelar na ADI n. 5.683/RJ, passa-se à análise da decisão monocrática proferida pelo Ministro Luís Roberto Barroso, que concedeu em parte a medida cautelar.

De início, o Ministro Barroso rejeitou a preliminar de redistribuição da ADI por conexão à Ação Cível Originária n. 2.981/RJ e as alegações de inconstitucionalidade formal da Lei Estadual n. 7.529/2017, que não são objeto desse estudo.

Quanto à inconstitucionalidade material, o Ministro afastou as alegações de violação ao artigo 37, da Constituição Federal, tendo em vista que "[o] Estado, diante da crise pela qual passa, tem autonomia para definir as medidas necessárias ao seu enfrentamento" ${ }^{27}$. Ainda nesse ponto, argumentou que o serviço prestado pela CEDAE é ineficiente e "a promoção de melhoria das condições de saneamento básico também se trata de uma competência político-administrativa do Estado" 28 .

Nesse ponto, cabe comentar que, não obstante o Supremo Tribunal Federal, na análise da constitucionalidade de leis e atos normativos, não esteja vinculado aos argumentos deduzidos na petição inicial, o Ministro Barroso parece analisar a questão da inobservância ao princípio da eficiência de ângulo diverso do apontado pelos autores da ADI.

\footnotetext{
25 Idem, ibidem.

26 BRASIL, Supremo Tribunal Federal. MC - ADI n. 5.683/RJ, Manifestação do Procurador-Geral da República, j. 29.08.2017, pp. 15-16.

27 BRASIL, Supremo Tribunal Federal. MC - ADI n. 5.683/RJ, Decisão monocrática do Ministro Luís Roberto Barroso, j. 29.08.2017, p. 16.

28 Idem, ibidem.
} 
Na petição inicial, a alegação de inconstitucionalidade da Lei n. 7.529/2017 do Estado do Rio de Janeiro perante o princípio da eficiência previsto no artigo 37, da Constituição Federal, se dá pelo fato de a CEDAE ser superavitária, de modo que a alienação das suas ações não contribuiria para o reequilíbrio das contas públicas estaduais. Já o Ministro Luís Roberto Barroso julga a questão da eficiência sob a perspectiva do serviço público prestado pela sociedade de economia mista.

De fato, a análise da eficiência da Administração Pública e de seus atos pode e deve ser realizada em diversas instâncias e perspectivas, contudo, não se pode deixar de observar que a ineficiência na prestação do serviço público pela CEDAE e a promoção de maior qualidade na prestação desse serviço público não são as motivações da alienação das ações representativas da empresa. Conforme se depreende do conteúdo da própria Lei e da mensagem de justificativa que acompanha o projeto de lei que lhe deu origem, as motivações para a autorização legislativa são o cumprimento do Termo de Compromisso firmado pelo Estado do Rio de Janeiro com a União Federal e a busca pelo reequilíbrio financeiro estadual.

Ao passar para a análise da alegação de violação do artigo 167, inciso III, da Constituição Federal, o Ministro Luís Roberto Barroso reconhece que se trata da "regra de ouro das finanças públicas" e afirma que "[p]or tal regra, a Constituição proíbe que o Estado financie as suas despesas por meio somente de endividamento, ou seja, apenas por meio de receitas de operações de crédito" 29 .

Em seguida, o Ministro, em interpretação literal do dispositivo constitucional, assevera que

essa regra não veda a utilização de receitas oriundas de operações de crédito para a realização de despesas correntes, mas determina que o montante das operações de crédito não pode exceder o montante das despesas de capital. Ou seja: o montante das despesas de capital deve ser maior ou igual às receitas de operações de crédito. A intenção é a de que o endividamento sirva a realização de investimento, não ao simples custeio do funcionamento da administração pública ${ }^{30}$.

Ainda, segundo o Ministro, a vedação do artigo 163, inciso III, da Constituição Federal não seria direcionada ao legislador que autoriza a operação de crédito e somente ao Poder Executivo que a contrataria, porque caberia a ele analisar se a operação de crédito excede ou não o montante das despesas de

29 BRASIL, Supremo Tribunal Federal. MC - ADI n. 5.683/RJ, Decisão monocrática do Ministro Luís Roberto Barroso, j. 29.08.2017, p. 16.

30 Idem, pp. 16-17. 
capital. Desse modo, a autorização legislativa não poderia ser considerada, por si só, inconstitucional.

No mais, considerando que "o impacto de uma decisão judicial na sociedade é uma dimensão que deve ser considerada”, o Ministro defende que devem ser ponderados os argumentos consequencialistas e o texto expresso da Constituição. ${ }^{31}$

Apesar da fundamentação elaborada pelo Ministro Luís Roberto Barroso para afastar a inconstitucionalidade da Lei em questão em face do artigo 167, inciso III, da Constituição Federal, não ser extensa, ela fornece múltiplos pontos para análise.

O primeiro ponto é a constatação de que o Ministro identifica esse dispositivo constitucional como a "regra de ouro das finanças públicas", acompanhando a doutrina majoritária, contudo, faz uma interpretação inovadora a respeito do que esse mandamento significa. De início, o Ministro Barroso sugere que não há qualquer óbice para que o Estado financie despesas - sem pormenorizar de qual espécie de despesas se está tratando - com operações de crédito, desde que tais despesas também tenham outras fontes de receita, ou seja, as operações de crédito não sejam a única fonte.

Infelizmente, o Ministro não desenvolve esse argumento para além da própria constatação, de modo que se torna difícil analisar a questão com maior profundidade, muito embora se registre que essa interpretação da regra de ouro não é usual na literatura sobre o tema. Nesse ponto, cabe comentar que, na interpretação tradicional da regra de ouro, de fato, a Constituição Federal não coloca óbice para que o Estado financie despesas com operações de crédito, desde que sejam despesas de capital, mas a fundamentação da decisão judicial ora em análise não faz essa distinção.

É provável que o Ministro Luís Roberto Barroso não faça distinção entre as espécies de despesa porque, em sua interpretação da regra de ouro, não há vedação à contratação de operação de crédito para financiar despesas correntes, em visão oposta à interpretação majoritária que se tem desse dispositivo constitucional, fundada exatamente na classificação das despesas públicas por categorias econômicas.

Ainda assim, o próprio Ministro lembra que a regra de ouro tem por objetivo garantir que as operações de crédito sejam realizadas visando a investimentos e não para custear o funcionamento da Administração Pública. Não se pode deixar de apontar a contrariedade entre essa constatação e a interpretação adota-

31 BRASIL, Supremo Tribunal Federal. MC - ADI n. 5.683/RJ, Decisão monocrática do Ministro Luís Roberto Barroso, j. 29.08.2017, p. 17. 
da pelo Ministro, no mesmo parágrafo de sua decisão monocrática, de que a regra de ouro não vedaria o financiamento de despesas correntes por meio de operações de crédito.

De uma forma geral, deve-se comentar que o Ministro Luís Roberto Barroso opta por uma interpretação literal do texto do artigo 167, inciso III, da Constituição Federal, sem deferência ao objetivo da norma ou à interpretação tradicional que se tem esse dispositivo.

O segundo ponto diz respeito à observação do Ministro Barroso de que a vedação presente na regra de ouro não comportaria a autorização legislativa pelo Poder Legislativo para a realização da operação de crédito e só a sua efetiva contratação no âmbito do Poder Executivo.

Deve-se considerar que ela está de acordo com a interpretação literal que foi adotada. No mais, é necessário pontuar que, ainda que se adote a interpretação tradicional da regra de ouro - de que há vedação constitucional à contratação de operação de crédito para custear despesas correntes -, a inconstitucionalidade também não se encontraria na autorização legislativa da operação de crédito em si, mas na previsão do artigo $2^{\circ}$, parágrafo $2^{\circ}$, da Lei Estadual n. 7.529/2017, que determina que tais recursos serão aplicados prioritariamente no pagamento da folha de servidores ativos, inativos e pensionistas, portanto, em despesas correntes.

O terceiro ponto a ser analisado é a consideração de que o texto expresso da Constituição Federal deve ser ponderado com argumentos consequencialistas. A par de todas as críticas que possam ser feitas a esse posicionamento, é necessário pontuar que, ainda que fosse o caso, o Ministro Barroso não faz, de fato, essa ponderação. O conflito entre valores constitucionais em um caso concreto não é estranho ao Supremo Tribunal Federal e o próprio tribunal já consagrou o uso do chamado princípio da proporcionalidade e dos seus critérios da adequação, da necessidade e da proporcionalidade em sentido estrito nessas situações. Contudo, apesar da alegada necessidade de ponderação, a aplicação dessa técnica não é nem ao menos cogitada na decisão.

Por fim, o Ministro Luís Roberto Barroso se dedica à análise da inconstitucionalidade da Lei Estadual n. 7.529/2017 em face do artigo 167, inciso X, da Constituição Federal, que determina:

Art. 167. São vedados: (...)

$\mathrm{X}$ - a transferência voluntária de recursos e a concessão de empréstimos, inclusive por antecipação de receita, pelos Governos Federal e Estaduais e suas instituições financeiras, para pagamento de despesas com pessoal ativo, inativo e pensionista, dos Estados, do Distrito Federal e dos Municípios.

Em face desse artigo, o Ministro reconhece que 
embora esse dispositivo em geral não pró́ba a concessão de empréstimos para pagamento de pessoal ativo, inativo e pensionista, ele veda a realização desse tipo de operação de crédito pelos Governos Federal e Estaduais e suas instituições financeiras. Ou seja, operações com essa finalidade podem ser realizadas por instituições financeiras privadas, mas não por aquelas controladas pelos Governos Federal e Estaduais ${ }^{32}$.

Portanto, o Ministro reconhece que há fumus bonis iuris em relação à inconstitucionalidade de uma das possibilidades interpretativas do artigo $2^{\circ}$, parágrafo $2^{\circ}$, da Lei Estadual n. 7.529/2017, que determina que os recursos obtidos com a operação de crédito serão prioritariamente destinados ao pagamento de servidores ativos, inativos e pensionistas, mas autoriza que essa operação seja feita com instituições financeiras nacionais, dentre outras, sem ressalvar as instituições financeiras estatais, em relação às quais há vedação constitucional, em razão do artigo 167 , inciso $\mathrm{X}$.

O Ministro Luís Roberto Barroso reforça o argumento lembrando a vedação infraconstitucional do artigo 35, parágrafo $1^{\circ}$, inciso I, da Lei Complementar n. 101/2000 (Lei de Responsabilidade Fiscal). ${ }^{33}$

Quanto a esse argumento, não há muito o que se comentar. É de se observar que o artigo 167, inciso X, da Constituição Federal, é bem específico e uma interpretação literal parece ser suficiente para sua aplicação no caso concreto.

Por fim, o Ministro reconhece a existência de periculum in mora, tendo em vista que, existindo autorização legislativa para a operação de crédito, ela poderia ser contratada e seus recursos destinados ao pagamento de servidores ativos, inativos e pensionistas, que, por ter natureza alimentar, geraria dano ao erário de difícil reparação.

Desse modo, concede parcialmente a medida cautelar "para o fim tão somente de afastar (...) interpretação que conduza à conclusão de que a operação de crédito autorizada pela Lei poderá ser realizada junto a instituições financeiras

32 BRASIL, Supremo Tribunal Federal. MC - ADI n. 5.683/RJ, Decisão monocrática do Ministro Luís Roberto Barroso, j. 29.08.2017, p. 19.

${ }^{33}$ Lei de Responsabilidade Fiscal. “Art. 35. É vedada a realização de operação de crédito entre um ente da Federação, diretamente ou por intermédio de fundo, autarquia, fundação ou empresa estatal dependente, e outro, inclusive suas entidades da administração indireta, ainda que sob a forma de novação, refinanciamento ou postergação de dívida contraída anteriormente.

$\mathbb{S} 1^{\circ}$ Excetuam-se da vedação a que se refere o caput as operações entre instituição financeira estatal e outro ente da Federação, inclusive suas entidades da administração indireta, que não se destinem a:

I - financiar, direta ou indiretamente, despesas correntes". 
estatais para pagamento de despesas com pessoal ativo, inativo e pensionista" 34 , até o julgamento final da ADI.

\section{CONSIDERAÇÕES FINAIS}

Desenvolvido esse estudo, podem ser tecidas algumas considerações finais.

De início, observa-se que, não obstante, em diversas peças processuais, se alegue que a alienação das ações representativas da CEDAE seja medida necessária ao cumprimento do Termo de Compromisso firmado entre o Estado do Rio de Janeiro e a União Federal, peça central nos esforços que objetivam a recuperação fiscal do Estado, o acordo prevê tão somente a realização de operação de crédito e a alienação das ações da empresa. Ou seja, em nenhum momento o Termo de Compromisso prevê que os recursos obtidos com essa transação sejam destinados ao pagamento da folha de servidores ativos, inativos e pensionistas.

Pelo contrário, a mesma cláusula do acordo que obriga o Estado do Rio de Janeiro a alienar suas ações representativas da CEDAE expressamente diz que deve ser observado o artigo 44, da Lei de Responsabilidade Fiscal ${ }^{35}$ que, por sua vez, veda a aplicação da receita de capital derivada da alienação de bens e direitos que integram o patrimônio público para o financiamento de despesas correntes.

Dessa forma, apesar da Lei Estadual n. 7.529/2017 ter sido editada para cumprir o acordo com a União Federal, o seu artigo $2^{\circ}$, parágrafo $2^{\circ}$, expressamente o contraria, exatamente no ponto em que haveria violação ao artigo 167 , inciso III, da Constituição Federal, em razão da destinação dos recursos obtidos com a operação de crédito conjugada à alienação das ações da CEDAE ao financiamento de despesas correntes.

É importante levantar esse tema para fazer mais uma ressalva. O ponto problematizado nesse artigo não é a alienação das ações - ou privatização - da CEDAE em si. De fato, essa decisão deve ser tomada pela Administração Pública do Estado do Rio de Janeiro, considerando sua população, a qualidade do serviço público prestado, os retornos financeiros da empresa e as necessidades para o equilíbrio financeiro estadual no curto, médio e no longo prazo.

Entretanto, independentemente de todas essas questões, o que se ressalta é a discussão acerca da compatibilidade jurídica - constitucional e legal - da contratação de operação de crédito e consequente alienação de ativos com a finalidade

${ }^{34}$ BRASIL, Supremo Tribunal Federal. MC - ADI n. 5.683/RJ, Ementa, j. 29.08.2017, p. 2.

${ }^{35}$ Lei de Responsabilidade Fiscal. "Art. 44. É vedada a aplicação da receita de capital derivada da alienação de bens e direitos que integram o patrimônio público para o financiamento de despesa corrente, salvo se destinada por lei aos regimes de previdência social, geral e próprio dos servidores públicos”. 
prioritária de arcar com despesas correntes, notadamente despesas com pessoal, e a decisão do Supremo Tribunal Federal diante dessa discussão.

Deve-se reconhecer que, não obstante trate-se do julgamento de uma medida cautelar e não do julgamento final acerca da constitucionalidade da Lei n. 7.529/2017, a argumentação da decisão monocrática, notadamente no que se refere à regra de ouro, é superficial.

Na verdade, não somente a decisão da medida cautelar, mas todas as manifestações processuais, inclusive a petição inicial, não tratam com profundidade da inconstitucionalidade da Lei Estadual em face do artigo 167, inciso III, Constituição Federal, focando seus argumentos nas alegações de inconstitucionalidade formal.

Contudo, é possível argumentar que, considerando que a interpretação adotada pelo Ministro Luís Roberto Barroso no que tange à regra de ouro das finanças públicas diverge da posição tradicional na interpretação do artigo 167, inciso III, da Constituição Federal, essa decisão mereceria uma fundamentação mais técnica e robusta.

A regra de ouro das finanças públicas, como o próprio nome indica, é norma fundamental na seara da responsabilidade fiscal. Apesar disso, é inexistente jurisprudência do Supremo Tribunal Federal, o último intérprete da Constituição Federal, sobre o tema. Pode-se considerar a possibilidade animadora de que isso aconteça devido à ausência de leis e atos normativos que potencialmente firam essa norma constitucional ou à inexistência, até o momento, de divergência interpretativa acerca do seu conteúdo. Por outro lado, também pode-se considerar a possibilidade mais negativa de que essa regra é desrespeitada, mas os atos que a contrariam não chegaram ao controle do Supremo Tribunal Federal ou, se chegaram, não foram julgados.

Considerando essa possibilidade, deve-se apontar a perda de oportunidade para uma discussão jurídica ampla e qualificada acerca do tema, notadamente diante do indício de que o tribunal pode dar interpretação mais restritiva à regra de ouro do que aquela existente na literatura sobre o tema. Isto posto, resta aguardar o julgamento final da ADI n. 5.683/RJ, quando e se ele acontecer, e esperar por um debate técnico que pacifique a interpretação do artigo 167, inciso III, da Constituição Federal.

\section{REFERÊNCIAS}

ANDRADE, Cesar Augusto Seijas de. Orçamento deficitário. In: CONTI, José Mauricio; SCAFF, Fernando Facury (coord.). Orçamentos Públicos e Direito Financeiro. São Paulo: Revista dos Tribunais, 2011, pp. 1159-1177.

ASSONI FILHO, Sérgio; BLIACHERIENE, Ana Carla; e ANDRADE, César Augusto Seijas de. Capítulo 4 - Dívida Pública. In: OLIVEIRA, Regis Fernandes de et. al. (coord.) Lições de Direito Financeiro. São Paulo: Editora Revista dos Tribunais, 2016, pp. 95-118. 
BARREIRA, Gabriel. RJ espera déficit de $R \$ 10$ bi em 2018, metade do previsto antes do Regime de Recuperação Fiscal, G1, Rio de Janeiro, 03 out. 2017. Disponível em $<$ https://g1.globo.com/rio-de-janeiro/noticia/rj-espera-deficit-de-r-10-bi-em-2018-metadedo-previsto-antes-do-regime-de-recuperacao-fiscal.ghtml>. Acesso em: 16 jul. 2018. BRASIL, Supremo Tribunal Federal. MC - ADI n. 5.683/RJ, j. 29.08.2017.

BRASIL. Termo de Compromisso que entre si celebram o Estado do Rio de Janeiro e a União. Disponível em <http://tesouro.fazenda.gov.br/documents/10180/0/Termo+ de+compromisso+RJ/81f7368e-43d6-4c90-ba45-e189db359f2a>. Acesso em: 16 jul. 2018.

CARTA CAPITAL. Entenda a crise e as razões da revolta de servidores no Rio de Janeiro. Carta Capital, 21 nov. 2016, Política. Disponível em <https://www. cartacapital.com.br/politica/entenda-a-crise-e-a-revolta-dos-servidores-no-rio-dejaneiro>. Acesso em: 16 jul. 2018.

CARVALHO JÚNIOR, Antonio Carlos Costa d'Ávila et al. Regra de Ouro na Constituição e na LRF: considerações históricas e doutrinárias - Estudo Técnico Conjunto n. 2/2017. Brasília: Consultoria de Orçamentos e Fiscalização Financeira da Câmara dos Deputados e Consultoria de Orçamentos, Fiscalização e Controle do Senado Federal, dez. 2017.

CARVALHO, José Augusto Moreira de. O orçamento a partir de seus princípios. In: CONTI, José Mauricio; SCAFF, Fernando Facury (coord.). Orçamentos Públicos e Direito Financeiro. São Paulo: Revista dos Tribunais, 2011, pp. 81-109.

ESTADO DO RIO DE JANEIRO. Anexo de Metas Fiscais da Lei de Diretrizes Orçamentárias 2018, p. 112. Disponível em <http://www.fazenda.rj.gov.br/sefaz/content/ conn/ UCMServer/path/Contribution\%20Folders/site_fazenda/Subportais/Portal PlanejamentoOrcamento/2_ppa_ldo_loa/ldo/ldo2018.pdf?lve>. Acesso em: 16 jul. 2018.

ESTADO DO RIO DE JANEIRO. Lei Orçamentária Anual 2018, p. 43. Disponível em <http://www.fazenda.rj.gov.br/sefaz/content/conn/UCMServer/uuid/ dDocName\%3aWCC207416>. Acesso em: 16 jul. 2018.

GIACOMONI, James. Orçamento Público. $17^{\mathrm{a}}$ ed. rev. e atual. São Paulo: Atlas, 2017. HARADA, Kiyoshi. Entendendo a regra de ouro das finanças públicas, 22 jan. 2018. Disponível em <http://www.haradaadvogados.com.br/2710-2/>. Acesso em: 16 jul. 2018. OLIVEIRA, Regis Fernandes de. Curso de Direito Financeiro. $3^{\mathrm{a}}$ ed. rev. e atual. São Paulo: Editora Revista dos Tribunais, 2010.

PIRES, Manoel. Para entender a regra de ouro das finanças públicas. In: Blog do Instituto Brasileiro de Economia da Fundação Getúlio Vargas, 01 nov. 2017. Disponível em <https://blogdoibre.fgv.br/posts/para-entender-regra-de-ouro-das-financaspublicas>. Acesso em: 16 jul. 2018.

PUFF, Jefferson. 4 motivos que levaram o Rio a decretar estado de calamidade pública. BBC Brasil, Rio de Janeiro, 18 jun. 2016. Disponível em <https://www.bbc. com/portuguese/brasil-36566996>. Acesso em: 16 jul. 2018.

SILVA, José Afonso da. Orçamento-programa no Brasil. São Paulo: Editora Revista dos Tribunais, 1973. 